https://doi.org/10.52240/1857-2367.2020.2(21).28

\title{
NOTE FLORISTICE DIN REZERVAŢIA ȘTIINŢIFICĂ „CODRU”
}

\author{
Pavel PINNZARU $U^{1}$, Valentina CANTEMIR ${ }^{l}$, Natalia JARDAN \\ ${ }^{I}$ Grădina Botanică Națională (Institut) "Alexandru Ciubotaru”, \\ Chișinău, Republica Moldova \\ ${ }^{2}$ Rezervația Științifică "Codru”
}

\begin{abstract}
Three new species of the flora of the "Codru" Scientific Reserve have been detected: Artemisia pontica L., Centaurea stereophylla Besser, Crataegus ucrainica Pojark. and new sites where some rare species grow have been identified.
\end{abstract}

Key words: flora, species, family, "Codru” Scientific Reserve, Republic of Moldova.

Cercetările floristice efectuate asupra vegetației din Rezervația Științifică "Codru", în cadrul proiectului 20.80009.7007.22 "Cercetarea și conservarea florei vasculare și macromicobiotei Republicii Moldova", au rezultat cu evidențierea a trei specii necunoscute anterior în flora acestei rezervații (Artemisia pontica L., Centaurea stereophylla Besser, Crataegus ucrainica Pojark.), locuri noi de creștere pentru unele specii rare. Totodată au fost observate unele particularităţi biologice, privind habitusul unor plante din luncă, şi anume, o creștere exuberantă, care întrece cu mult dimensiunile citate în literatura de specialitate. Astfel, flora vasculară a rezervației, în conformitate cu publicațiile mai recente [1-6] și în baza noilor cercetări, cuprinde 957 de taxoni. Speciile Equisetum pratense L. și Dactylorhiza majalis (Rchb.) P.F.Hunt \& Summerh. [1], în urma precizărilor taxonomice, nu cresc în Rezervația Științifică "Codru” [2, 4]. Taxonii evidenţiaţi urmează în continuare:

Artemisia pontica L. (Asteraceae) - este înregistrată prima dată în flora rezervației. Vegetează în grupuri mici, în poienile "Păunului" (parcela 43), în fitocenoze de Inula salicina L. cu Euphorbia valdevillosocarpa Arvat et Nyár. [= E. volhynica auct. mold. non Besser ex Racib.], 21.VII.2020, 11.X.2020, leg. P. Pînzaru, V. Cantemir, N. Jardan [CHIS - herbarul Grădinii Botanice Naționale (I) "Al. Ciubotaru"]. Plantele de Artemisia pontica înfloresc în luna septembrie, ating înălțimea de $60-80 \mathrm{~cm}$. 
Centaurea stereophylla Besser (Asteraceae) - este evidențiată prima dată în flora rezervației. Crește sporadic pe o colină ierboasă din preajma stației meteorologice, 22.VII.2020, leg. P. Pînzaru, V. Cantemir [CHIS]. Plantele înfloresc în luna iulie, ating înălțimea de până la $95 \mathrm{~cm}$.

Crataegus ucrainica Pojark. (Rosaceae) - prezenţa acestui taxon în flora rezervaţiei a fost constatat în urma revizuirii colecției herborizate, privitor la genul Crataegus, din cadrul GBNI [CHIS], material colectat 17.VII.1984, leg. T Gheideman. Specie rară, înregistrată în subarboret, în fitocenoze de stejăret cu fag.

Galium rivale (Sibth. \& Sm.) Griseb.[= Asperula rivalis Sibth. \& Sm.] (Rubiaceae) - în rezervație era cunoscută numai din luncă, parcela nr. 12 [5]. Un loc nou de creștere a fost înregistrat în poienile din pădurea de luncă cu Quercus robur L., parcela nr. 55, 19.VIII.2020, leg. P. Pînzaru [CHIS]. Sporadic crește în fitocenoze cu ierburi înalte: Angelica sylvestris L., Eupatorium cannabinum L., Thalictrum lucidum L., Cirsium arvense (L.) Scop., Epilobium hirsutum L., Filipendula ulmaria (L.) Maxim. etc. Plantele înfloresc în lunile iulie-septembrie, ating înălțimea de circa $80-90 \mathrm{~cm}$.

Serratula coronata L. [= S. wolffii Andrae] (Asteraceae) - această specie a fost semnalată prima dată pentru flora rezervației de către N. Sturza [6], înregistrată în poienile "Păunului", parcelele 43 și 52. Un nou loc de creștere a fost înregistrat în poiana din pădurea de luncă cu Quercus robur L., parcela nr. 55, 22.VII.2020, leg. P. Pînzaru, C. Cantemir, 11.IX.2020, leg. P. Pînzaru [CHIS]. Înflorește în lunile iulie-septembrie, maturizarea semințelor are loc în luna septembrie, plantele din luncă ating înălțimea de până la $230 \mathrm{~cm}$.

În cadrul cercetărilor floristice, efectuate în această rezervaţie, în decursul perioadei de vegetaţie a anului 2020, au fost observate creşteri exuberante în înălţime a unor plante din vegetația de luncă: Pimpinella major (L.) Hudson (165 cm), Cirsium oleraceum (L.) Scop. $(185 \mathrm{~cm})$, Carduus crispus L. $(225 \mathrm{~cm})$, Senecio erucifolius L. $(215 \mathrm{~cm})$, Thalictrum lucidum L. $(270 \mathrm{~cm})$, Inula helenium L. $(230 \mathrm{~cm})$.

\section{BIBLIOGRAFIE}

1. Negru A., Jardan N. Flora. În: Conspectul diversității biologice a Rezervației "Codrii”. Chișinău: Știința, 2011. P. 78-184.

2. Pînzaru P., Cantemir V. Floristic notes in Bessarabia no. 165-200. În: Journal of Botany, vol. X, Nr. 2(17), 2018. P. 32-41.

3. Pînzaru P., Jardan N. Ophioglossum vulgatum L. (Ophioglossaceae) - specie nouă în flora Rezervației științifice "Codru” din Republica Moldova. În: Mater. Conf. șt. nat. cu participare intern. 27-28 sept. 2019. Chișinău: Tipogr. UST. P. 45-48.

4. Pînzaru P. Pteridofitele din Republica Moldova. Chișinău: Tipogr. UPS "Ion Creangă", 2019, 121 p.

5. Sturza N. Sherardia arvensis L. și Asperula rivalis Sibth. et Sm. din familia Rubiaceae - specii noi în flora Republicii Moldova. În: Mater. Simpoz. Jub. Rezervația "Codrii” - 35 ani. Lozova, 2006, p. $92-93$.

6. Sturza N. Noi completări la Lista speciilor de plante din Rezervaţia "Codrii”. În: Mater. Simpoz. Șt. Inetren. Rezervația ”Codrii” 40 de ani. Chișinău: Știința, 2011. P. 376-378. 